\title{
Skove omkring Sønderborg
}

Skoven som ressource 1500-1800

\author{
af CHRISTIAN Bo BOJESEN
}

Træ har udgjort en vigtig ressource $\mathrm{i}$ historien. Som leverandør af bygningsmaterialer og brændsel har skoven været en vigtig forudsætning for udviklingen af by- og landbrugssamfundet. Men historien om skoven som ressource er samtidig historien om en langvarig konflikt mellem menneske og miljø. I artiklen tegner forfatteren et billede af skovens tilstand og udbredelse omkring Sønderborg og af, hvordan skoven her har været udnyttet i tre århundreder.

Der har været masser af skov omkring Sønderborg tilbage i historien. Træ var en vigtig ressource som bygningsmateriale. Alene anlægget af det første slot ved Sønderborg samt alle de senere ændringer og tilbygninger har krævet store mængder træ. Dertil kommer husene i byen omkring slottet. Træ har naturligvis også været anvendt som varmekilde. Man har fyret med træ, men også med trækul, før stenkullene kom til under den industrielle revolution. Den tidlige teglværksindustri i området har givetvis også krævet mængder af træ. Desuden er skovenes løv og olden (agern/bog) blevet anvendt til dyrefoder, og bønderne har brugt træ til hegn (gærdselstræ). Omkring 1500 blev det første orlogsskibsværft i Sønderborg bygget. Skibe - og specielt orlogsskibe - var særdeles ressourcekrævende. En beregning viser, at der er gået cirka 1.000 egetræer til bygning af kong Hans' orlogsskib Engelen i 1510 - svarende til et område på knap to hektar egeskov. Også under Frederik I var der gang i skibsbyggeriet i Sønderborg, og Christian III benyttede skibsværftet til udrustning af hele ti skibe i perioden 1534-1536. Skovene omkring Sønderborg har således skullet klare meget.

Historien om skoven som ressource er historien om en langvarig konflikt mellem menneske og miljøet. Fortidens voldsomme ressourceforbrug af træ har sat sig sine tydelige spor $\mathrm{i}$ det landskab, vi ser $\mathrm{i}$ dag. Vi skal i løbet af artiklen se, at det gik specielt hårdt for sig i områderne Mintebjerg, Lambjerg, Klinting, Sundsmark, Ulkebøl, Dyndved, Skovby, Lysabild, Mommark og Kegnæs. 
Men er det overhovedet muligt at skabe et billede af skovenes tilstand og udbredelse omkring Sønderborg i perioden 1500-1800? Et muligt svar på det spørgsmål tager sit udgangspunkt i Bo Fritzbøgers undersøgelser om danske skove 1500-1800. ${ }^{1}$ I sit værk indkredser han en række betydningsfulde faktorer som over- og underskov, primær og sekundær skov samt naturskov. Han opstiller desuden en række kriterier, der kan bruges til bestemmelse af skovenes udbredelse i Danmark i perioden 1500-1600, hvor vi kun har få kilder og sjældent direkte udsagn om skoven. Det bedste materiale er landkort, men de findes ikke, når vi går længere tilbage end 1600. Fritzbøgers metode kaldes retrospektiv, fordi historikeren går tilbage i historien fra de nutidige kort og landskabsbilleder via andre kanaler som stednavne, regnskaber, love og beskrivelser fra breve og dagbøger. Artiklen her støtter sig til hans metode og begreber. ${ }^{2}$

\section{Als i forhistorisk tid}

På mange måder er Als en privilegeret ø. Området omkring Ulkebøl og Hørup sogne er et af Danmarks mest frugtbare. Jordbunden består af fedt, ofte stenfattigt moræneler, som er aflejret $i$ istiden. Isen har aflejret det medslæbte materiale, der ved boringer omkring Sønderborg har vist tykkelser på 45 meter - øst for Hørup 62 meter. $^{3}$ Sommertemperaturen og især forårstemperaturen er højere end længere nordpå, men nedbørsmængden er gennemsnitlig for Danmark. Det betyder bedre vækstbetingelser for eksempelvis korn og frugt. ${ }^{4}$

Alt tyder på, at Als og Sundeved ligesom store dele af det øvrige Danmark tilbage i historien har været meget skovrig. I Danmark afløstes tundraen tilbage $\mathrm{i}$ forhistorisk tid af udstrakte fyrreskove, hvor birk og bævreasp dannede overgangen. Et vigtigt element til fastsættelse af denne udvikling er pollenanalysen. ${ }^{5}$ I et pollendiagram fra Bundsø på Als kan vi følge landskabsudviklingen gennem bronzeog jernalderen (se side 135). Vi kan se fordelingen af træ- og urtepollen, som afspejler balancen mellem skov og åbent land over tid i venstre side af diagrammet. I højre side vises fordelingen af træarterne $i$ skoven, skyggetræerne lind og bøg til venstre, fugtighedsbundsskov og åben skov i midten og endelig elleskov til højre. I denne frugtbare egn har landskabet altså siden begyndelsen af bondestenalderen været præget af menneskelig aktivitet, og ressourceudnyttelsen har været betydelig. ${ }^{6}$ 
Pollendiagrammet fra

Bundsø på Als viser landskabsudviklingen gennem bronze- og jernalderen. Her har landskabet siden begyndelsen af bondestenalderen været præget af menneskelig aktivitet, og ressourceudnyttelsen har været betydelig. Gengivet efter Svend Th. Andersen: Fra urskov til kulturskov. Ugeskrift for jordbrug 1987.

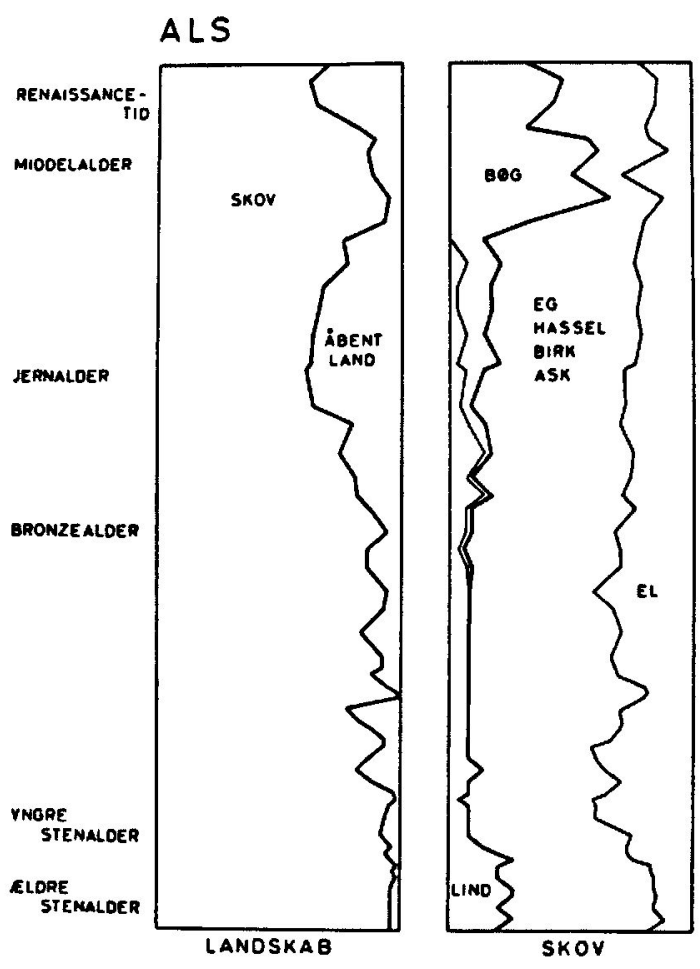

\section{Bøgen i bronzealderen}

Skovenes ressourcer blev også brugt $\mathrm{i}$ bronzealderen, hvor landskabet rummede betydelige skovarealer. De vekslede med store, åbne landbrugsarealer, der enten blev dyrket eller henlå som græssede overdrev. Her indvandrede bøgen i ældre bronzealder cirka 1500 f.Kr. Den kom til Danmark på et tidspunkt, hvor andre træarter var veletablerede, og den var i en lang årrække forholdsvis sjælden, da dens naturlige voksesteder på mere tør bund blev udnyttet til landbrugsformål. Skovene på Als var således lysåbne og næsten domineret af eg og hassel på de tørre arealer, og af eg, ask og el i de mere fugtige områder. Lind og elm, som tidligere havde været så almindelige, var nu sjældne i skovbilledet, fordi de blev brugt som løvfoder til husdyr og tovværk (lindebast).

I slutningen af ældre jernalder omkring 400 e.Kr. var der tale om en tilbagegang $\mathrm{i}$ bebyggelsestætheden. De arkæologiske spor efter 
Udsigt mod Lambjerg og Hørup indtagt. I middelalderen var dette område dakket af skov, men fra midten af 1500-tallet blev skoven ryddet. I samtiden var der tale om en logisk og sund foroaltning af de forhaindenvarende naturlige ressourcer. I dag ville vi kalde det rovdrift. Foto: Christian Bo Bojesen.

landbruget, som eksempelvis skovrydning og pløjespor, forsvinder. Skoven genindtog store nu områder. For Als' vedkommende kan det tydelig ses på pollendiagrammet, men det skete overalt i Sønderjylland, også på de tungere jorde. Pollenprøver fra den sønderjyske og østholstenske kyst tyder på, at området i perioden $400-800$ e.Kr. var tyndt befolket. Det betød, at området igen groede til med skov, og i jernalderens sidste halvdel resulterede en mindre temperaturstigning sammen med et fugtigere klima $i$, at bøgetræet kom til at dominere. Der er således en sammenhæng mellem bøgeskovens ekspansion og perioder med svag kulturaktivitet. 


\section{Vikingetid og middelalder}

Mens de nye bosættelser, der blev anlagt i vikingetid og tidlig middelalder, kun ryddede mindre skovarealer til marker, var højmiddelalderen præget af, at store dele af skovene blev hugget om og omdannet til åbne kulturlandskaber. Denne udvikling kan også følges i pollendiagrammet. I perioden omkring Den sorte Død (1347-1352) og den efterfølgende ødegårdsperiode i 1300-tallet kan man igen se en sammenhæng mellem tilbagegang $i$ landbrug og skovens generobring af landskabet. Igen var det bøgeskoven, der ekspanderede. På trods af betydelige rydninger stod der stadig meget skov tilbage. Den blev på 
forskellig vis brugt til byggemateriale, brænde, garvebark, strøelse og løvhø. Den stærkt voksende befolkning på landet og byerne i 1200tallet medførte en øget efterspørgsel på byggemateriale og brænde. Der blev anvendt træ til skibsbyggeri og fremstilling af trækul til brug ved jernudvinding og i smedjerne. ${ }^{7}$

\section{Perioden 1500-1700}

I denne periode skete der for alvor noget i skovene, som nu blev intensivt udnyttet. Ved siden af vedproduktion var græsning til kvæget og olden til svinene vigtig. Modsat den gamle blandingsskovs træer er bøgeskud ikke særligt tiltrækkende for kvæg, og det kan have fremmet bøgens udbredelse. Tidligere tiders svinehold i skovene kan have medvirket til at skabe og opretholde bøgens dominans. Særlig forholdet mellem eg og brg kan belyse dette. Svin synes at foretrække agern fremfor bog. Svin æder unge egeplanter - men ikke unge bøgeplanter, og svin skræller endog gammel eg dødeligt, mens al bøg er urørt. ${ }^{8}$ Klimaændringer i skovenes sammensætning bevirker, at ask og ahorn breder sig stærkt i visse skovpartier - f.eks. i Arnkilskovens (også kaldet "Spøgelseskoven «) fredede nordlige del. Her ser man, at bøgen, som er enerådende $\mathrm{i}$ overskoven, ikke kan forny sig i skovbunden. Ahorn og ask breder sig i underskoven, og deres skygge hindrer bøgens fornyelse, mens den gennemkultiverede Sønderskov beherskes af bøgen. ${ }^{9}$ De mange bøgeskove omkring Sønderborg i dag er tilplantet kulturskov, og det er umiddelbart vanskeligt at se, hvilke områder, der har holdt sig selv ved lige, og dermed er efterkommere af de tidlige bøgeskove.

\section{Kongelige forordninger om beskyttelse af skovene}

Fra omkring $1500 \mathrm{og}$ frem til slutningen af 1700 gik det hårdt til i skovene. Den voldsomme udnyttelse af skovenes ressourcer resulterede $i$, at der fra centralmagten blev udsendt bestemmelser, der varetog hensynet til skove, træer og tilplantning i skove. Allerede i sidste halvdel af 1500-tallet omtales varige stengærder som middel til at spare træ. ${ }^{10}$ Christian III forsøgte med en forordning i 1544 at skride ind mod træhugst til byggeri, idet ingen nørrejyder måtte "bruge fjæletømmer eller bulvægge i deres huse", men kun bruge sten og ler. Det hjalp tilsyneladende ikke meget, for Frederik II måtte i 1577 gen- 
Brud-egene ved Kathrinelund. Foto: Christian Bo Bojesen.

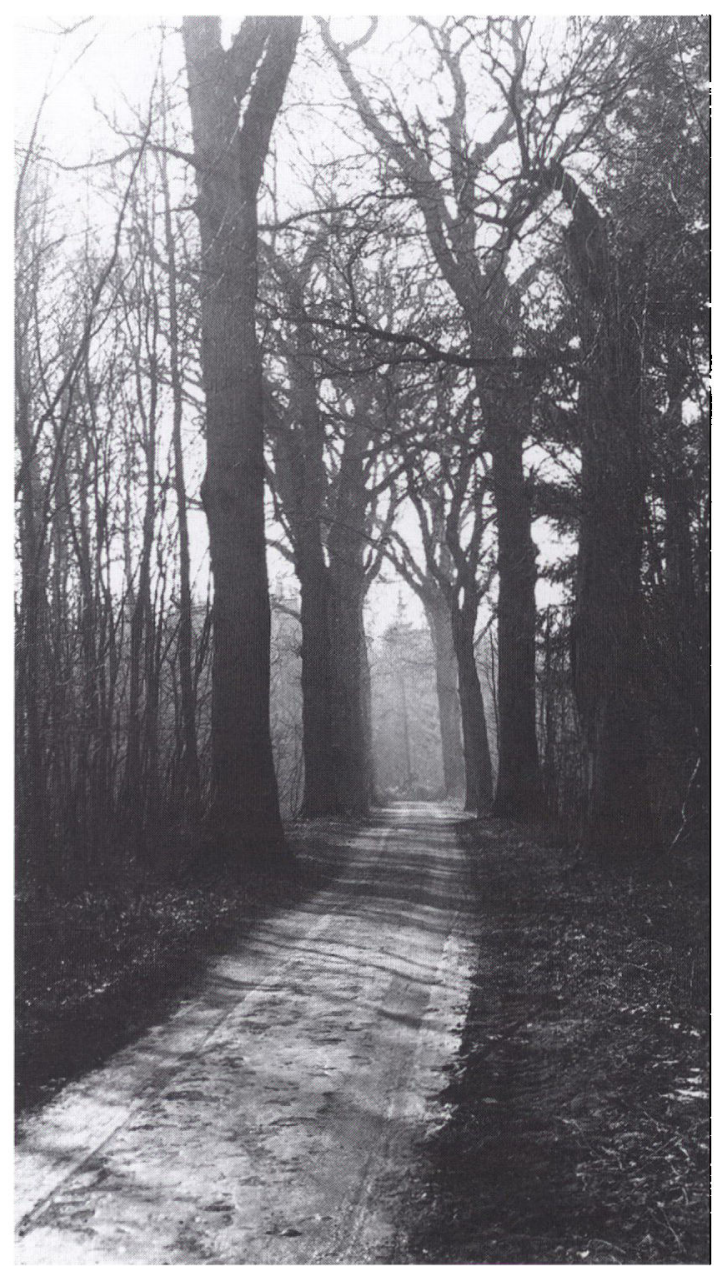

tage forbuddet overfor bønderne i Koldinghus og Skodborg Len, hvor hans hovedargumenter var, at huse af træ var farlige ved ildebrand og tilmed skadelige for skoven. I en reces fra 1547, dækkende hele riget, bestemmes det, at hver bonde skal sætte ti piletræer, og meget tyder på, at tilsvarende regler hele tiden har været gældende mange steder i riget - altså også på Als. I Nordborg skulle hver boelsmand fra 1686 årligt »sætte 60 pile« og "besætte dem med levende gærder, hessel og torn«. Plantebestemmelsen var en ordre, som findes i fæstebreve og i Danske Lov fra 1683.11 At befolkningen på Als også fór 
hårdt frem mod skovene, ses $\mathrm{i}$ et kongeligt brev til Axel Viffert på Nyborg slot i 1572: „Da bønderne på Ærø og Als lider stor mangel på brændsel, skal han skaffe dem sådan for betaling af fornede [frønnede] træer og vindfælder i kronens skove på Als og Ærø, og, hvis der ikke er nok der, i Fyn, hvor der ikke sker skovskade«. I 1618 udstedes en direkte ordre til stiftslensmændene og bisperne overalt $i$ riget om "at have flittigt tilsyn med skovene«, og at der kun må hugges træ til kirker og hospitaler, uden at der bliver gjort skade på skovene. I 1619 får lensmændene overalt $i$ riget besked om at påse, "at de selvejerbønder, som holder soldater, ikke forhugger sine skove « ${ }^{12}$

Efter enevældens indførelse i Danmark i 1661 med dens stigende ønske om at kontrollere og topstyre alle led i samfundet, kommer skovene for alvor på landkortet. Enevælden ser det som et vigtigt mål at bremse ødelæggelsen af skovene af hensyn til jagt og forsyningen med tømmer til flåden. Denne politik kan følges i Frederik III's "Forordning om jagten i vildtbanen « til beskyttelse af skov og vildt, hvor hensigten først og fremmest er at beskytte jagten. Men derefter lægger forbud fra Christian V op til en generel beskyttelse af skovene. ${ }^{13} \mathrm{I}$ Christian V's forordninger bliver begreber som over- og underskov defineret, og de træarter, der går igen, er eg og bøg - de vigtigste træsorter indenfor skibsbyggeri. Der opstilles nøje bestemmelser og regler for færdsel i skov, brug af skov, bevarelse af skov og skovhugst. Afslutningsvis følger sanktioner for de enkelte misbrug og overtrædelser. Fra Christian V's hånd kommer der efterfølgende mange forordninger, for eksempel den 12. oktober 1676 og 31. august 1680 . Heraf fremgår det tydeligt, at der har været store problemer med overholdelse af de tidligere bestemmelser, og at situationen $\mathrm{i}$ skovene er blevet værre. Derfor betones det atter og atter, hvor vigtigt det er med genplantning af træer, specielt af bøg og eg. ${ }^{14}$ På Als udstedte hertug August i 1636 og hertug Ernst Günther af Augustenborg i 1696 en forordning for skovbyerne Stenholt, Huholt og Vollerup om, at unge folk, som ønskede at blive gift, skulle plante ti unge ege i skoven og pleje dem i syv år. ${ }^{15}$ I 1737 blev det forordnet, at parret inden vielsen skulle have plantet ti ege eller 15 bøge og forevist attest for øvrigheden, inden præsten måtte vie dem. Brudgommen skulle sørge for træernes vedligeholdelse i tre år. I 1787 ophørte denne form for træplantning i skovene omkring Hørup. Selv om Pontoppidan i Den danske Atlas nævner, at det var så som så med ordningens overholdelse, kan man på strækningen mellem Kathrinelund og Huholt og i Nørre- og Sønderskoven stadig se nogle af disse ege i rækker eller grupper. 
Centralmagtens klare mål var altså at hjælpe skoven, og grundene hertil har været mangfoldige - blandt andet kongens og adelens interesse for jagt. Jagten var et led $\mathrm{i}$ opdragelsen af adelsmænd, og det forudsatte, at nogle skove skulle stå urørte, så dyrelivet kunne være det bedste til jagtformål. Denne beskyttelse af udvalgte skove er samtidig et tegn på, at der var interesse for at råde bod på omgivelsernes - primært bøndernes - indhug i skovene. Initiativerne gik først og fremmest ud på at redde de gamle bøge- og egeoverskove, som havde været i stærk tilbagegang. Hullerne efter bøndernes udnyttelse af skoven skulle de selv fylde ud. Bønderne brugte træet $\mathrm{i}$ underskoven til stort set alt inden for landbruget: byggeri, gærder, redskaber og brænde. Ydermere fungerede skoven som foderplads for specielt svin. Dette aspekt skal vi vende tilbage til senere.

Måden, hvorpå bønderne år efter år huggede i underskoven, gav karakteristiske spor, som kan ses nogle steder som stevningstræer. De er karakteristiske med stub og strittende grene som resultat af hugsten.

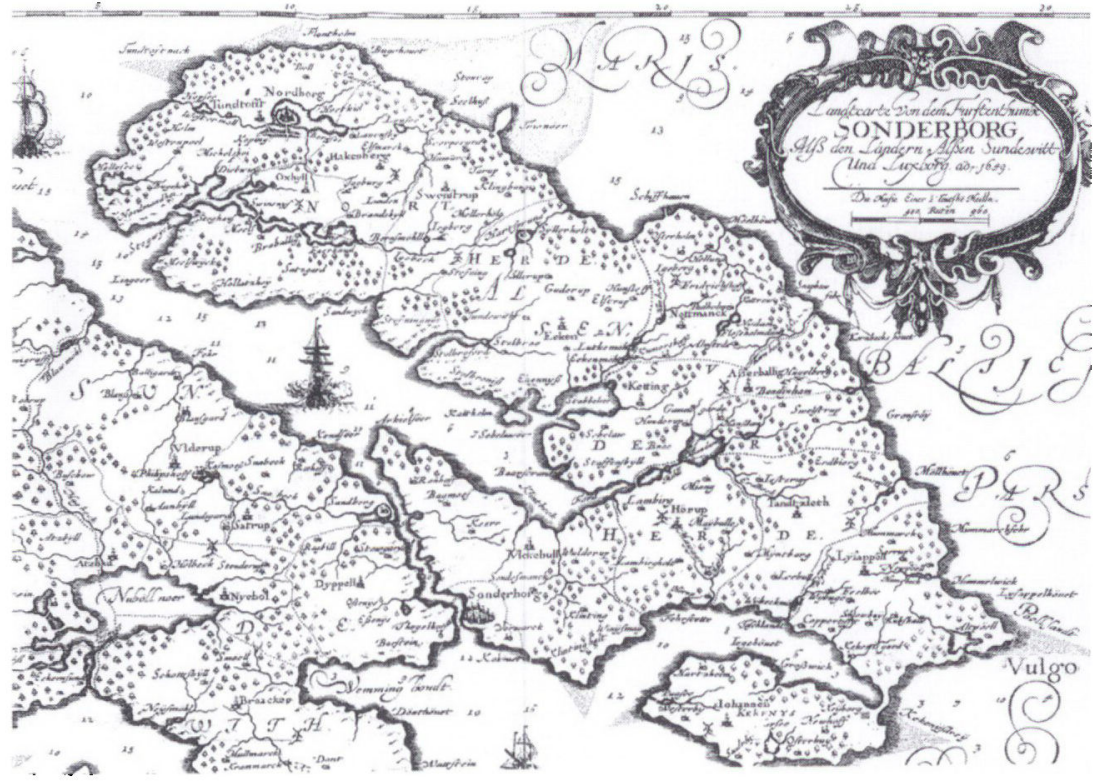

Det ældste kort over Als. Bemærk skovsignaturerne. Kobberstik efter Johannes Mejers tegning, dateret 1649. Foto: Museet på Sønderborg Slot. 


\section{Undersøgelser af skovens tilstand før 1600}

Når vi skal tilbage til tiden omkring 1500, er kilderne særdeles sparsomme. Vi ved, at Kegnæs frem til 1615 var dækket af skov, men at hertug Hans lod halvøen rydde. Desuden ved vi, at de første bysamfund på Als er begyndt på de lettere jorder på øens vestkyst, fordi den daværende plovtype endnu ikke kunne klare den tunge, lerede jord. Landsbydannelsen gik derfor langsomt, og det var først hen i jernalderen og ind $i$ middelalderen, at man igen indvandt ny landbrugsjord. Og endeligt aftegner det arkæologiske materiale vejen Klinting - Horup - Tandslet som en ryddet forbindelse $i$ jernalderen. ${ }^{16}$ Derudover er det muligt at skitsere skovens situation i disse tidlige tider ved at studere skovens udbredelse på de ældste kort og beskrivelser og derfra slutte bagud i tiden.

En anden vigtig kildetype er stednavnene med endelserne -holt, -ry, -rod, -elle, -ved, -skov. Hvis man begynder med at se på et nutidigt kort, får man et overblik over skovenes status i dag. Derefter kan man gå retrospektivt til værks og gå tilbage til de ældste kort over

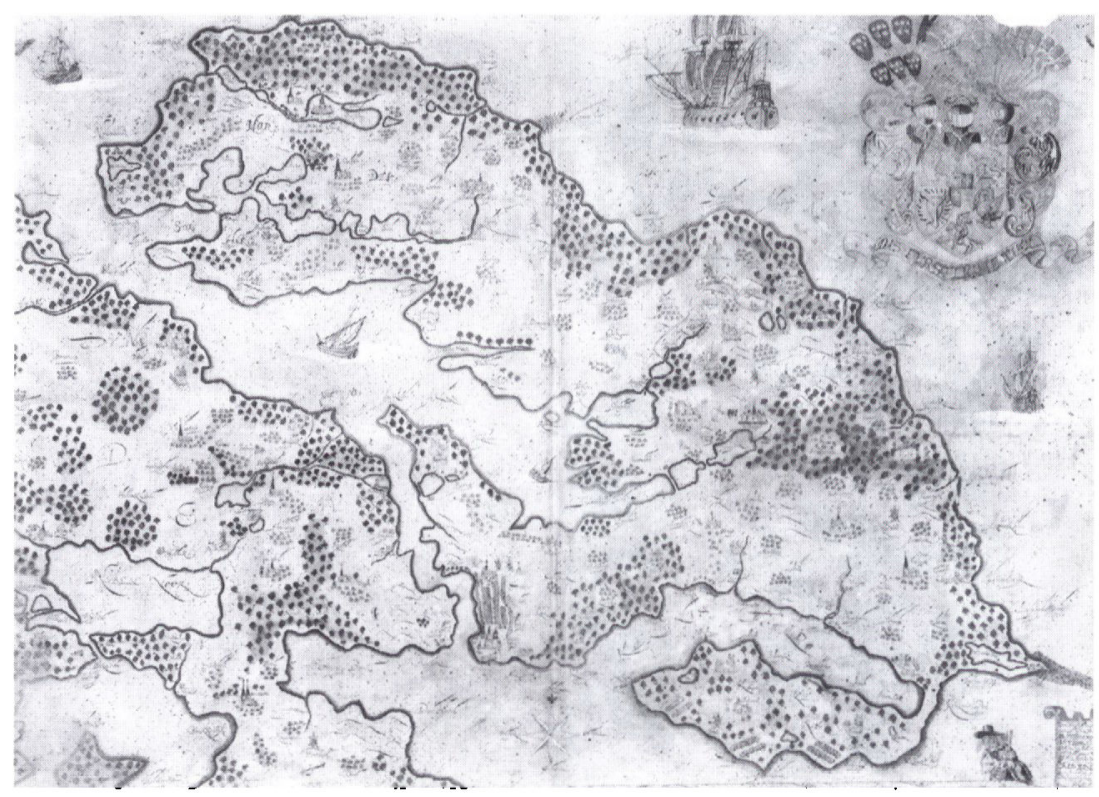

Heinrich Ottendorffs kort fra 1655 med skovsignaturer. Originalkortet findes i Kortsamlingen på Det Kongelige Bibliotek. Foto: Museet på Senderborg Slot. 
området. Eksisterende skove er jo de bedste kilder til lokalisering af skove, som er kendt fra andre kilder. Går vi tilbage til de tre ældste kort, der dækker området, er der Johannes Mejers kort fra henholdsvis 1649 og 1652, og Henrich Ottendorffs fra 1655. Gamle kort indeholder mange data, hvad angår skovenes udbredelse. De angiver ved signaturer lokaliseringen af skov og ved forskellige signaturer plantetætheden og bevoksningens karakter, som kan tillade et skøn over udbredelsen. I de tilfælde, hvor der er påskrevne navne, kan vi oven i købet få en identifikation af de pågældende skove.

Mejers kort fra 1649 hænger sammen med Danckwerths Landesbeschreibung der Herzogthümer Schleswig und Holstein fra $1649 .{ }^{17}$ Her står der om Als, at hele østkysten udgør en sammenhængende skovstrækning lige fra Hellesø på Als' nordspids og lige ned til Drejet ved Kegnæs i syd. Skovene ligger spredt i området med Sønderskoven som én af de større. Derimod findes der ingen skov på Stolbronæs på Als' vestkyst. Ligeledes findes skov langs Kegnæs' nordlige kyst og igen på en strækning af den sydlige kyst.

Man kan derfor ved sammenligning af forskellige tiders kort bruge disse som én af vejene til at opstille en formodning om tilstanden tilbage i tiden - også i perioden 1500-1650. Udskiftningskortene fra landboreformerne er $\mathrm{i}$ høj grad anvendelige $\mathrm{i}$ studier inden for det meget nære område. Det er klart, at de ældste kort indeholder fejlkilder, idet deres målestok gør, at skovsignaturer ikke har den præcision, som vi forventer af vore dages kort.

\section{Stednavne}

Stednavne er meget konservative og vidner i mange tilfælde indirekte om skov, hvorfor man her kan inddrage bebyggelsesnavne samt mark- og naturnavne. Der er to elementer, som kan bruges til bestemmelse af skov, nemlig navne, der peger på skovrydning og udflytning i middelalderen, og navne, der dækker utvetydig bebyggelse i skov. ${ }^{18}$ Følgende oversigt belyser dette spørgsmål for bebyggelser, der er indgået i Sønderborgs ressourceområde på Als og på Jyllandssiden. ${ }^{19} \mathrm{De}$ rydningsnavne der er behandlet her, giver et fingerpeg om skovenes udbredelse. Rydning har selvfølgelig været brugt $\mathrm{i}$ andre områder og omkring andre byer, hvis navne bare ikke har mindelser om decideret skovrydning. Men hvis man samler alle skovindicerende navne og stiller dem over for byer med øvrige bynavne, er der visse forskellig- 
heder mellem de enkelte områder. Forskellene findes i skovrydningsmetoden, der er anvendt og $i$ omfanget af rydningen. Endelig er byernes alder også vidt forskellige. Tandslet er et godt eksempel på en særlig voldsom rydningsmetode, idet arealet simpelthen er ryddet ved afbrænding.

De spredte bebyggelser af gårde og huse opstod ved, at kådnere flyttede ud fra de gamle overbefolkede landsbyer og gav sig til at rydde skov. Kådnere var det nederste lag i hierarkiet i landbrugssamfundet. De havde som regel blot et lille hus, eventuelt med et lille stykke jord. Udflytter- og skovrydningsbevægelsen begynder som nævnt i middelalderen og fortsætter op i tiden.

For områdets vedkommende er det meget karakteristisk, at de nævnte bynavne eller endelser, der opstår i middelalderen, alle har noget med skov og rydning af skov at gøre, og det kan ses som en bekræftelse på, at området i middelalderen har været meget skovrigt.

\section{Lensregnskaber og oldensvin}

Til belysning af undersøgelsen om skovsammensætning og skovenes udstrækning kan lensregnskaber anvendes. Af disse regnskaber fremgår blandt andet afgifter i træ. Resultaterne fra den undersøgelse vil i det følgende blive sammenlignet med Johannes Mejers kort over Als for at afdække rydningsområderne. Desværre er der kun overleveret regnskaber fra Sønderborgområdet fra 1524 og 1535. Men selv om oplysningerne er få, er det ikke ensbetydende med, at de aktiviteter,

\begin{tabular}{|l|l|l|l|}
\hline Endelse & Betydning & Byer & Tidligste navn \\
\hline Inge & $\begin{array}{l}\text { Meget gammel endelse. Betegner bebo- } \\
\text { erne det pågældende sted. Beboerne pd̊ } \\
\text { klinten. Ketting har formodentlig noget } \\
\text { med kat at gøre. Egen kan betyde Beboer- } \\
\text { ne ved egene. }\end{array}$ & $\begin{array}{l}\text { Klinting } \\
\text { Ketting } \\
\text { Egen }\end{array}$ & $\begin{array}{l}\text { Clintyngy/1231 } \\
\text { Ketyngy/1231 } \\
\text { Yking/1357 }\end{array}$ \\
\hline Vang & $\begin{array}{l}\text { Endelsen - vang kan være dannet i vi- } \\
\text { kingetiden, men nogle er senere - for- } \\
\text { modentlig fra middelalderen. I Dan- } \\
\text { mark har ordet făet en speciel betyd- } \\
\text { ning: Indhegning eller indhegnet skov. } \\
\text { Miang=smal vang }\end{array}$ & Mjang & Meyangk/1483 \\
\hline By og Toft & $\begin{array}{l}\text {-by betegner næsten altid landsbyer. - } \\
\text { toft dækker det område, der hører til et } \\
\text { hus. Endelser fra vikingetid og middel- } \\
\text { alder. }\end{array}$ & $\begin{array}{l}\text { Skovby } \\
\text { Sønderby } \\
\text { Østerby }\end{array}$ & $\begin{array}{l}\text { Skouby/1373 } \\
\text { Grundlagt o. 1600 } \\
\text { Grundlagt o. 1600 }\end{array}$ \\
\hline
\end{tabular}




\begin{tabular}{|c|c|c|c|}
\hline Endelse & Betydning & Byer & Tidligste navn \\
\hline Torp & $\begin{array}{l}\text { Ordets ældste betydning er landgdrd. I } \\
\text { nutiden ender de på -rup. Middel- } \\
\text { alderudflytninger. }\end{array}$ & $\begin{array}{l}\text { Sottrup } \\
\text { Ullerup } \\
\text { Vollerup } \\
\text { Hørup } \\
\text { Sarup } \\
\text { Jestrup } \\
\text { Elstrup } \\
\text { Svenstrup } \\
\text { Torup }\end{array}$ & $\begin{array}{l}\text { Zatorpe } / 1434 / \\
\text { Sottrup/1436 } \\
\text { Ugelthorp } / 1352 \\
\text { Woldorp } / 1483 \\
\text { Hodorp } / 1483 \\
\text { Sadorp/1423 } \\
\text { Jesstorp } / 1483 \\
\text { Elefstorp } / 1245 \\
\text { Swenstorppe/1431 } \\
\text { Torp/1543 }\end{array}$ \\
\hline Bøl & $\begin{array}{l}\text { Dækker betydning som bol, bosted eller } \\
\text { en gård. I de allerfleste navne er ordet } \\
\text { brugt om menneskelige bosteder. De } \\
\text { fleste -belnavne har personer som for- } \\
\text { led. Fra vikingetid og middelalder. }\end{array}$ & $\begin{array}{l}\text { Dybbøl } \\
\text { Ragebøl } \\
\text { Avnbøl } \\
\text { Nybøl } \\
\text { Ulkebøl } \\
\text { Lebøl } \\
\text { Brandsbøl } \\
\text { Oksbøl } \\
\end{array}$ & $\begin{array}{l}\text { Duttebul/1352 } \\
\text { Rakebul/1400 } \\
\text { Auenthbull/1483 } \\
\text { Nybull/1352 } \\
\text { Ulkebole/1245 } \\
\text { Lebul/1423 } \\
\text { Bramsbole/1197 } \\
\text { Oxebuel/1483 }\end{array}$ \\
\hline $\begin{array}{l}\text { Lokke og } \\
\text { Have }\end{array}$ & $\begin{array}{l}\text { I navne fra ældre tid bruges ordene } \\
\text { især om indhegninger p\& gammelt } \\
\text { skovland. Stammer fra middelalderen. }\end{array}$ & Ronhave & \\
\hline Mark & $\begin{array}{l}\text {-mark har på oldnordisk betydningen } \\
\text { skov//demark og indgår i rydningsnavne. } \\
\text { Forleddet er som oftest et personnavn }\end{array}$ & $\begin{array}{l}\text { Sundsmark } \\
\text { Mommark } \\
\text { Notmark } \\
\text { Elsmark }\end{array}$ & $\begin{array}{l}\text { Sundæmarck/ } \\
1483 \\
\text { Momark/1423 } \\
\text { Nuthmarck/1341 } \\
\text { Elismark/1423 } \\
\end{array}$ \\
\hline Slet & $\begin{array}{l}\text { Betyder rydning og indgår i rydning- } \\
\text { snavne. Nogle steder indgắr et led, der } \\
\text { viser, at rydningen er foregået med ild. } \\
\text { Tandslet = areal ryddet ved afbrænding. }\end{array}$ & Tandslet & Tandeslete/1183 \\
\hline Ved & $\begin{array}{l}\text { Et gammelt dansk ord for skov er -ved } \\
\text { og på gammeldansk -with. Grundbetyd- } \\
\text { ningen er grænse og derefter grænseskov. } \\
\text { Helleved kan betyde den hellige skov til- } \\
\text { bage fra vikingetiden. Dyndved nok } \\
\text { skoven ved mosen. }\end{array}$ & $\begin{array}{l}\text { Sundeved } \\
\text { Helleved } \\
\text { Dyndved }\end{array}$ & $\begin{array}{l}\text { Sundwitt (Valde- } \\
\text { mars jordebog) } \\
\text { Helwith } 1649 \\
\text { Dundewyth } / 1483\end{array}$ \\
\hline Holt & Fra middelalderen. Betyder lille skov. & $\begin{array}{l}\text { Huholt, } \\
\text { Stenholt }\end{array}$ & Steenholtt/1604 \\
\hline Skov & $\begin{array}{l}\text { Lysabild=Liusapeld } / 1245 \text {. Æbletræ. } \\
\text { Lius=lys - om blomsterne. Almsted in- } \\
\text { deholder trænavnet } \text { elm. Katryd=Kat- } \\
\text { try } / 1649 \text {. Ellekrat indgår i Tandselle. Det } \\
\text { forsvundne Benneris i Hørup inde- } \\
\text { holder krat. }\end{array}$ & $\begin{array}{l}\text { Almstedskov } \\
\text { Notmarkskov } \\
\text { Hundslevskov } \\
\text { (forsvundet) } \\
\text { Kettingskov } \\
\text { Asserballeskov } \\
\text { Ertebjergskov } \\
\text { Sarupskov } \\
\text { Lambjergskov } \\
\text { Hørupskov } \\
\text { (Forsvundet) }\end{array}$ & $\begin{array}{l}\text { Alm./Halmstad/ } \\
1245 \text {. }\end{array}$ \\
\hline Boge & Vi er et gammelt hedensk offersted. & Vibøge & Wiboki/1245 \\
\hline Roirs & Tyder på tidligere skov=rydning & $\begin{array}{l}\text { Maibøliroi } \\
\text { o. lign. }\end{array}$ & \\
\hline
\end{tabular}


der belyses i regnskaberne, ikke har fundet sted i tidligere og efterfølgende år. Regnskaberne er skatteregnskaber og afspejler tydeligt fast sædvane og indgroede traditioner.

Skovens indskrænkning medførte efterhånden, at man opgav den hidtidige udnyttelse med oldensvin i skovene. Oldensvin var tamsvin, der blev drevet ud i skovene, hvor de levede af olden (bog og agern). Fortidens skove, som ikke blev drevet rationelt som i dag, var meget mere produktive med hensyn til olden. Derfor er oldensvin med til at give et billede af ege- og bøgeskovenes tilstand i middelalderen. Rydningen af skovene fremmede godsdriften og agerbruget. Resterne af skoven blev sparet til brændsel, gavntømmer og ikke mindst til jagt. Rydningen er naturligvis også sket med henblik på forbedring af fæstegårdenes drift. ${ }^{20}$ Fra områdets lensregnskaber findes en oversigt, som indirekte giver oplysninger om ege- og bøgeskovene via opgørelserne om oldensvin. ${ }^{21}$ "Folk give ikke oldengæld i Sønderborg len, men når der er olden, hvert femte svin; de, der ikke have så mange svin, at de kunne give hvert femte, give for hvert svin 4 skilling lybsk [...] når der er god, fuld olden, får man fra Kegnæs og andre skove 2-3.000 svin. Fordelt på fem år bliver det hvert år 500 svin «. ${ }^{22}$

Det er altså tale om mange oldensvin, hvilket oversigten herunder også er et udtryk for. Oversigten er lavet på baggrund af oplysninger fra områdets lensregnskaber:

\begin{tabular}{lll}
\hline Årstal & Område & Antal svin på olden \\
\hline 1524 & Regnskaber fra Sønderborg Slot & 1500 svin \\
\hline $1535,1540,1543$, & Regnskaber fra Sønderborg Slot & 500 svin hvert år \\
$1544,1545,1546$ & Kegnæes og de andre skove & $3-4.000$ svin \\
\hline 1595 & Nordborg, Helvedgård, Gammel- & 2.000 svin fra hver \\
& gård, Lysabild, Avnbøllund & gård \\
& Kegnæs & 1600 svin \\
\hline 1597 & Øens mange skove & 5.300 svin \\
& Kegnæs & 18.000 svin \\
\hline 1604 & Sundeved & 1.003 svin \\
& Als & 6.428 svin \\
& Kegnæs & 3.280 svin \\
\hline 1649 & Halvøen Kegnæs har forhen været & 910.000 svin \\
& lutter skov, så der i gode år kunne \\
& holdes 910.000 svin & \\
\hline
\end{tabular}




\begin{tabular}{lll}
\hline 1662 & $\begin{array}{l}\text { Hørup Østerskov } \\
\text { Lambjerg Skov }\end{array}$ & $\begin{array}{l}50 \text { svin } \\
150 \text { svin }\end{array}$ \\
\hline $1667-1668$ & $\begin{array}{l}\text { Meget lidt olden i Hørup Østerskov } \\
\text { og Lambjerg Skov }\end{array}$ \\
\hline $1669,1681,1694$ & $\begin{array}{l}\text { Megen olden i Hørup Østerskov } \\
\text { Lambjerg Skov }\end{array}$ & $\begin{array}{l}45 \text { svin } \\
70 \text { svin }\end{array}$ \\
\hline Omkring 1800 & $\begin{array}{l}\text { Ingen olden af betydning i Hørup } \\
\text { Østerskov og Lambjerg Skov }\end{array}$ \\
\hline
\end{tabular}

Det voldsomme tal i 1597 og 1649 for Kegnæs' vedkommende må være en skrivefejl, formentlig begået af præsten Christian Knudsen, som samlede og afskrev dokumenter fra præste-, kirke- og sognearkiver. ${ }^{23}$ Men de spredte oplysninger om de mange oldensvin giver oplysninger om store bøge- og egeskove. Bortset fra Kegnæs og få andre skove kan vi ikke sige præcist, hvilke skove på Als der er tale om, og hvor store de har været på det tidspunkt.

En opgørelse over amternes godsindtægtskilder i 1544 bekræfter dette billede og giver en udmærket konklusion på den relative fordeling af skove $i$ hertugdømmet Slesvig.

\begin{tabular}{|l|c|}
\hline $1544 /$ mark & Olden \\
\hline Haderslev & 60 \\
\hline Torning & 100 \\
\hline Aabenraa & 20 \\
\hline Senderborg & 510 \\
\hline Nordborg & 100 \\
\hline Flensborg & 137 \\
\hline Tonder & 254 \\
\hline Gottorp & 300 \\
\hline
\end{tabular}

Denne fordeling af indtægterne viser tydeligt, at Sønderborg og Als havde relativt meget ege- og bøgeskov i midten af det 16 . århundrede.

\section{Mængden af brænde tyder på rovdrift}

Landgildeydelsen læs optræder i mange jordebøger omkring $1500 .{ }^{24}$ Betaling med brændeved stammer fra den tid, da bønderne havde 
på skoven er tydelig. Situationen er ved at vende til det værre i midten af det 17. århundrede.

\section{Trækulsproduktion}

Der blev også anvendt træ til brænding af trækul i miler, og det omtales i Danmark for første gang i begyndelsen af 1500-tallet. Kilderne viser tydeligt, at det var bøndernes arbejde. Ser man det fra bøndernes side, er der en væsentlig forskel på, om det var hoveripligt, eller de kunne gøre det med salg for øje. Lensregnskaberne fra Als viser, at der blev brændt kul, og det tyder på, at det hørte under hoveripligt. ${ }^{26}$ De få kildesteder fra Fyn og Jylland i form af forleningsbreve viser, at trækul indgik som en del af naturalierne i lensmandens løn. Endvidere tyder kildematerialet på, at det var en pligt, som oftere og oftere blev påtvunget. Kildematerialet afspejler i høj grad kronens behov, og de peger på Skåne, Halland, Blekinge og Sjælland som centret. Trækul er en skrøbelig vare at transportere, og derfor omtales landsdelene tæt ved København oftere end andre områder. Men det tyder på, at bønderne overalt, hvor der var skov i Danmark, havde den fornødne viden om brænding af trækul, idet det indgik i mange processer. Således brugte smedene trækul før stenkullet blev almindeligt. I alle håndværk, hvor man smeltede, støbte og loddede metaller, var trækullene uundværlige. Allerede fra 1506 opførte kong Hans' dronning Christine adskillige gange om året milekul i sine hushold-

1533 Af 11 bønder i Skelde ydede én afgift i form af træ Af seks bønder i Stenderup ydede to afgift i form af træ

1550 Afgift til Sønderborg slot på to favne brænde fra en bonde

1565 I Dybbøl Barthel Knudsen [...] 3 favne brænde Marquartsen [...] 8 favne brænde Sønderborghus 50 favne brænde

1589 Hørup præsteskov er ikke forhugget, forbedres årligt ved ungskov

1676 Hørup præsteskov er forhugget

1683 Ansøgning til kongen om tømmer fra hans skove til reparation af Lysabild kirke

1795 En del af skoven i Hørup ryddes $\mathrm{i}$ forbindelse med udskiftningen 
ningsregnskaber. Trækulsbrænding har også fundet sted i området omkring Sønderborg og på Als. ${ }^{27}$

Det har umiddelbart vist sig at være problematisk at beregne hvor meget træ, der rent faktisk går til at brænde én kubikmetertrækul. Skov- og Naturstyrelsen og Jagt- og Skovbrugsmuseet har desværre ingen beregninger. Men kulsvierlauget i Nordsjælland i Gribskov har lavet forsøg, og her er man nået frem til, at $3 \mathrm{~m}^{3}$ træ giver ca. 500 $\mathrm{kg}$ trækul. Disse oplysninger har dannet udgangspunkt for følgende beregninger:

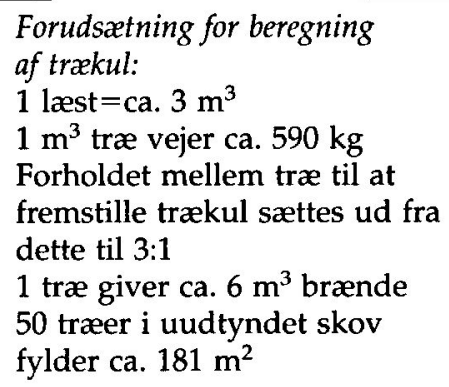

Forudsatning for beregning af brændeved:

1 læs brænde svarer til et vognlæs

1 læs fylder ca. $2 \mathrm{~m}^{3}$

1 træ giver ca. $6 \mathrm{~m}^{3}$ brænde 50 træer i uudtyndet skov fylder ca. $181 \mathrm{~m}^{2}$

Ifølge lensregnskaberne blev der i 1524 afleveret 60 læster trækul og 678 læster trækul i 1535, hvilket i alt giver 738 læster. ${ }^{28}$ Beregningen fører frem til, at der til trækulsfremstilling i årene 1524 og 1535 må være blevet fældet $4.007 \mathrm{~m}^{2}$ skov til dette formål. Omsættes brændeveddet tilsvarende i skovareal, bliver det til, at der i alt blev fældet $4.210 \mathrm{~m}^{2}$ skov i 1524 og 1535 . Sammenlagt er ca. $8.217 \mathrm{~m}^{2}$ skov blevet afleveret i afgift i 1524 og 1535 i Sønderborgområdet, og det er værd at huske, at vi ikke taler om al den skov, der blev fældet i 1524 og 1535 , men kun om den, som figurerer i regnskaberne som skat. Derfor er beregningen og resultaterne kun et fingerpeg om arealet af den samlede skovning $i$ de to år.

Beregning af skovhugst på baggrund af lensregnskaber

\begin{tabular}{lrr}
\hline & 1524 & 1535 \\
\hline Antal træer til brændeved & 546 & 1.017 \\
Antal træer anvendt til trækul & 90 & 617 \\
Antal træer i alt & 636 & 1.634 \\
$\mathrm{~m}^{2}$ skov & 2.302 & 5.915 \\
\hline
\end{tabular}

Samlet antal $\mathrm{m}^{2} 8.217 \mathrm{~m}^{2}$ 
Stigningen i trækulsproduktionen fra 60 til 678 læster er interessant. På 11 år må der åbenbart være sket en øget efterspørgsel efter trækul. Hvorfor? Måske øget efterspørgsel til smedeværksteder, saltsydning, krudtfremstilling eller andet?

Der er kun overleveret regnskaber fra disse to år, men hvorfor er der ikke lensregnskaber fra flere år? Det er sandsynligt, at de simpelthen er gået tabt. Et len kunne nemlig ikke fungere uden en administration, der havde kontrol over indkomsterne i form af skatter og afgifter. Det fører til den næste antagelse om, at der er skovet hvert år. Men for ikke at opstille for usandsynlige beregninger er 1524 og 1535 afgrænsningen for beregningen.

Materialet tyder på, at træhugsten er accelereret kraftigt. Inden for 11 år er der således sket en fordobling af den samlede skovhugst. Hvis man foretager en lavt sat gennemsnitsberegning ud fra tallene 1524 og 1535, er der i perioden hvert år skovet $8.217: 2=4.108 \mathrm{~m}^{2}$. Det giver over perioden på de 11 år ca. 4,5 ha. ${ }^{29}$ Tallet er helt sikkert meget højere, da det som sagt kun er muligt at opstille teorien ud fra skattetal og ikke den totale mængde af fældet skov. Men tallene tillader den konklusion, at skovene omkring Sonderborg virkelig blev brugt som ressourceområde fra omkring $1550 \mathrm{og}$ frem.

Jordebogsregnskaberne viser de vigtigste skovningsområder: Mintebjerg, Lambjerg, Klinting, Sundsmark, Ulkebøl, Vollerup, Dybbøl, Dyndved, Skovby, Lysabild og Mommark. Lægger man disse områder ind på Mejers kort fra 1649, dækker de groft sagt de hvide felter, som er markeret på kortet. Mejers signaturer har måske ikke været helt hen i vejret, så talberegning og kortet kan tages som tungtvejende indicier herfor.

\section{Hertug Hans den Yngre - en initiativrig mand}

Hertug Hans den Yngre (1545-1622) ændrede meget $\mathbf{i}$ ordningen af handel og bymarker. Hele Als og Sundeveds topografi blev - ikke mindst hvad angår skove - dybtgående ændret som følge af hertugens driftige landbrugs- og godspolitik. Vi ved fra regnskaberne fra hans gods Ahrensböck i nærheden af Lübeck, at skovbruget spillede en meget vigtig rolle $\mathbf{i}$ godsdriften dér. Hertug Hans lod bygge savmøller, og en vigtig indtægtskilde blev salg af træ. Én af hemmelighederne bag hertugens store indtægter kan altså være regulær skamhugst af træ med salg for øje. ${ }^{30}$ Hans foretagsomhed på Als - 


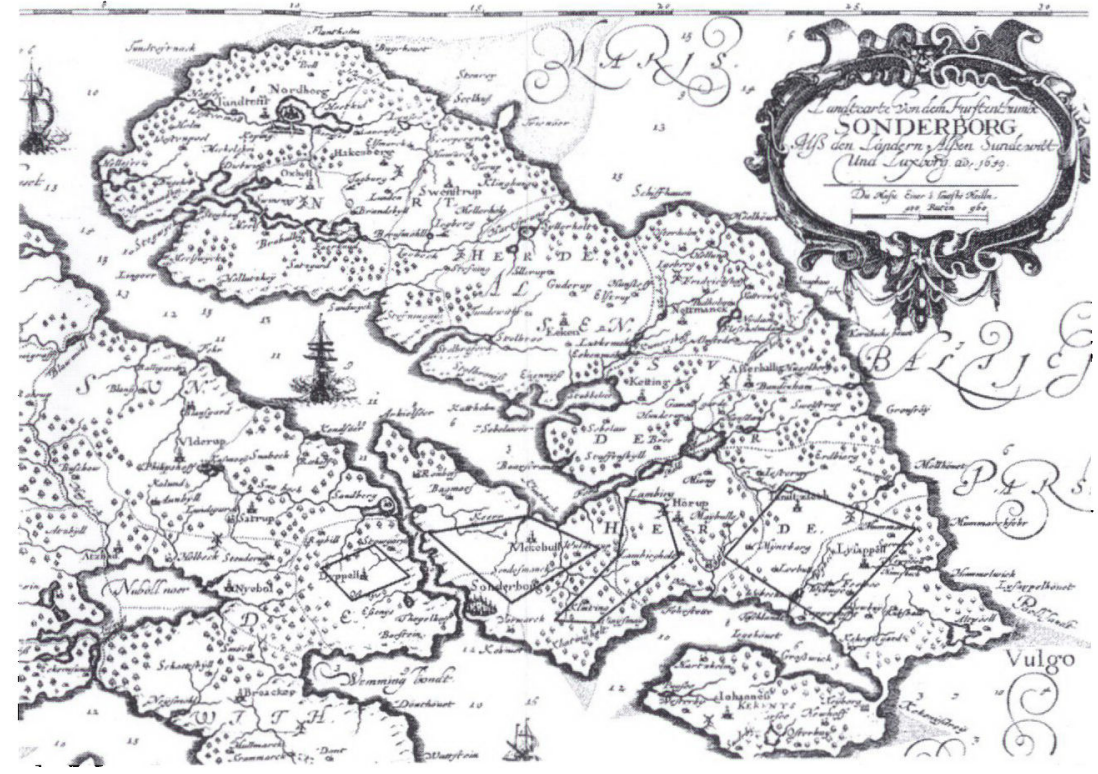

De tunge skouningsområder er markeret her pd Johannes Mejers kort fra 1649. Foto: Museet på Sonderborg Slot.

specielt på Kegnæs - var den samme som på Ahrensböck. Hertug Hans fik således på bedste moderne iværksættervis to mål opfyldt. Han øgede sine indtægter ved at hugge skove om og sælge træet, og skovene blev ryddet af fæstebønder for at indvinde ny landbrugsjord. I dag ville vi kalde hans mål og planer for en miljømæssig katastrofe, men målt med datidens forhold var hertugen fremsynet og initiativrig. Danmark var et periferiområde i Europa, og landbruget var det bærende erhverv. Kornpriserne var stigende, hvilket skyldtes prisrevolutionen i Europa som følge af de store opdagelser omkring 1500. Det nød Danmark som korn- og kvægproducerende land godt af. Hertug Hans' politik skal ses i lyset af denne udvikling. Hans linje med godssammenlægninger og udflytning af bonder til skovrydning afveg på ingen måde fra periodens almindelige godsejerpolitik.

Nær Sønderborg slot indrettede hertugen et saltsyderi, og muligvis har der været et andet nær ladegården Rønhave. ${ }^{31}$ Hvad det har krævet af træ at drive disse syderier, er nok ikke muligt præcist at nå frem til. Men ser man på de tidligere beregninger fra jordebogsregnskaberne, har det været meget. Et eksempel herpå findes på Anholt, 
hvor skovene i perioden $1500-1600$ blev totalt udraderet, netop fordi der skulle bruges træ til saltsydning.

På et stik, der viser angrebet fra den kejserlige hær fra Brandenburg og indtagelsen af Sønderborg den 14. december 1658 under svenskekrigene, kan vi se, at lige omkring Sønderborg er skovene væk, og at der er et åbent bælte ud mod Ladegården og Sønderskoven. I dag udgør dette bælte Skratmosen. På udsnittet af stikket er der marker, og dette kan godt harmonere med Mejers kort. På stikket og prospektet af Sønderborg fra 1770 (se næste side) ses Ladegården yderst til højre. Den var anlagt af Hertug Hans den Yngre, og den tilhørte slottet. I 1781 skriver Pontoppidan i Den danske Atlas: "Langenvorwerk i Ulkebøl sogn kaldes også ladegård, og ligger straks østen for Sønderborg slot, nær havet. Den er nu en stor og prægtig gård, men har i førstningen været meget liden, indtil adskillige grunde fra Ulkebøl, Vollerup, Sundsmark kom hertil. [...] Skov er her i mængde, mest bøg og elletræer.«

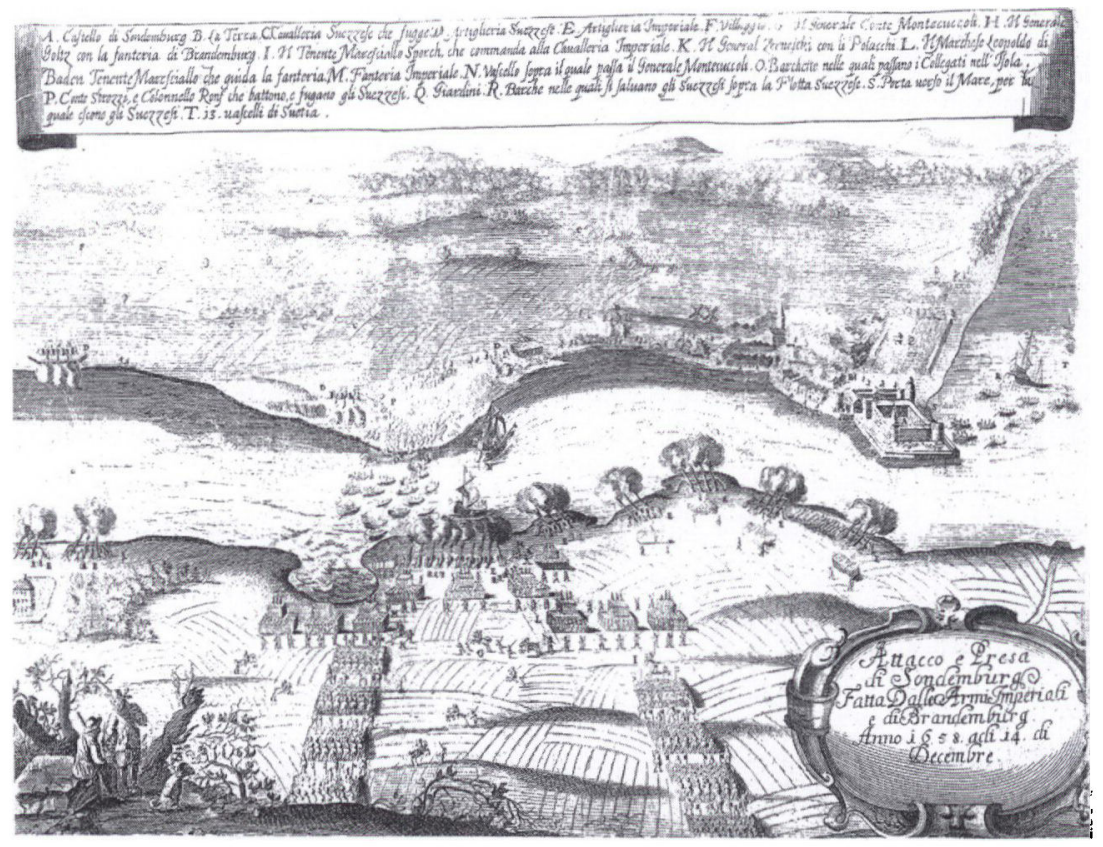

Stik, der viser angrebet og indtagelsen af Sonderborg foretaget af den kejserlige hær fra Brandenburg den 14. december 1658. Stikket viser, at der var et äbent bxilte ud mod Ladegården og Sonderskoven. Skovene var altså væk lige omkring Sønderborg. Foto: Museet på Sonderborg Slot. 


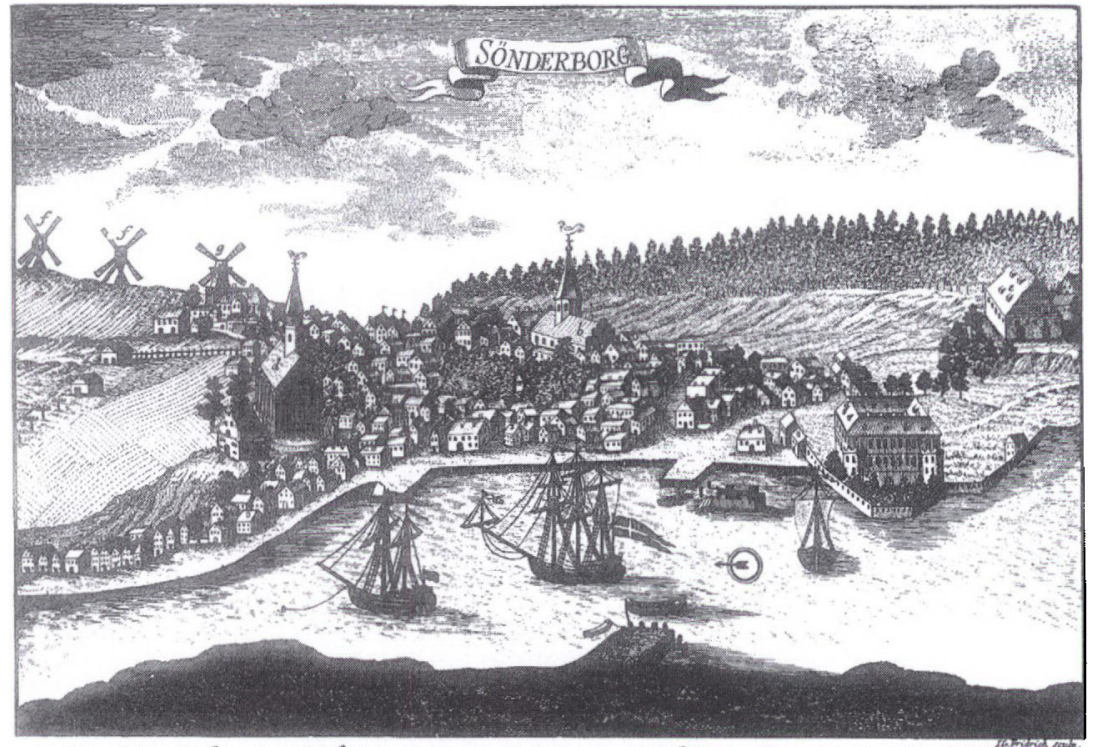

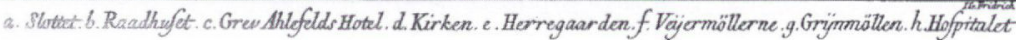

Prospekt fra Danske Atlas 1770, som viser, at området omkring Ladegården (yderst til højre) var frodigt og vedligeholdt. Men ellers var der afskovet. Skovene onikring Sonderborg blev faldet $i$ cirkler begyndende nærmest byen. Foto: Arkivet ved Dansk Centralbibliotek for Sydslesvig.

Billedet af skovens udbredelse er altså ændret på cirka 100 år. Det kan være unøjagtigheder $\mathrm{i}$ de to prospekters gengivelse, men det er formentlig et godt udtryk for den faktiske udvikling, fordi Pontoppidans beskrivelse og skovbeskrivelsen fra 1730 understøtter dette. Beskrivelserne tyder på, at Ladegården og området lige omkring Ladegården har været frodigt og vedligeholdt. Men ellers har der været afskovede områder, så skovene omkring Sønderborg er blevet fældet i cirkler begyndende indefra nærmest byen.

\section{Det skovrige og frugtbare Als i 1600-tallet}

Generelle beskrivelser af Als omkring 1650 karakteriserer øen således: Øen »har herlig træfrugt i store frugthaver [...] på skov og engkrat er der heller ingen mangel «. Hele området med Als, Fyn og Langeland var frugtbart med eng, skov, vildt og fiskeri. I en cirka 100 år senere 
Arter af træer pá baggrund af optælling af gårdnavne pá Als og Sundeved fra Geodætisk instituts málebordsblad 1964

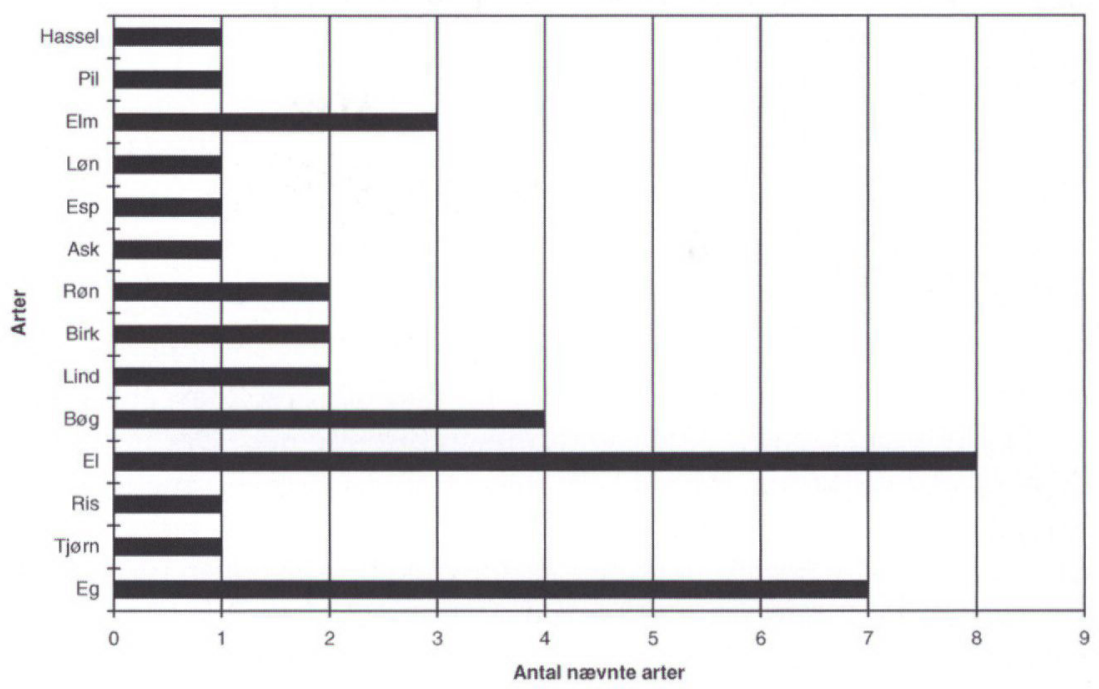

beskrivelse tales der om, at der transporteres brænde til København. Det vil sige, at Als har haft så meget træ, at der har været overskudsproduktion. Især på "Als, Sundeved [...] findes de skønneste og behageligste egne, som giver rug [...] Disse egne have god skov, « hedder det i Danckwerths beskrivelse. ${ }^{32}$ Der har været meget gamle træer, for i 1763 skriver præst J. A. Dyssel om en tur til Nordborg: »Der begynder en prægtig og bred allé, som løber lige til Nordborg slot. Denne allé må ellers være meget gammel, da træerne er af overmåde tykhed [...] træerne var skammeligt forhuggede «.33 I 1795 stod der 5.379 træer på 650 tdr. land på Gammelgårds marker: 3.500 ege, 1.370 bøge, 351 ask, 70 løn, 69 elle, 69 elme. Alle disse træer gik senere til brændsel. I 1799 var der 745 ege og 609 bøge i præstegårdsskoven i Hørup. ${ }^{34}$ Alle disse træer kan mageligt være fra omkring 1600. I sit topografiske værk om hertugdømmerne beskriver Johannes Schröder »Als' østlige del som skovrig « i modsætning til vestdelen. Og for omkring 150 år siden beskrev botaniker Vaupel skoven ved Ulkebøl som én af de typiske danske egeskove, der kan give os et fingerpeg om, hvordan den gamle skov har set $u^{3}{ }^{35}$

Mark- og gårdnavne, der indeholder træarter, er en anvendelig kilde, når man skal forsøge at lokalisere forskellige trætyper. Agerdyrkning og ny jord er jo $\mathrm{i}$ høj grad flettet sammen med skoven. Men der 
skal naturligvis tages en række forbehold ved anvendelsen af en sådan kildetype. Hvor tydelig skulle en plantebestand for eksempel være for at give navn til et område? Betegnelsen må have været bestemt af omgivelsernes opfattelse af den vigtigste træart. En les optælling ud fra Geodætisk Instituts kort fra 1964 giver et fingerpeg om, at el og eg især indgår i mange gård- og marknavne.

\section{Brandtræet - et særligt træ}

Brandtræet udgør en hel speciel gruppe af træer. Brandtræerne blev opfattet som tabutræer og måtte derfor ikke fældes. Blev et sådant træ fældet ved en gård, ville ejendommen brænde ned. Der indgår et element af overtro og myte i opfattelsen af disse træer, men måske også et element af erfaring, idet træerne måske har fungeret som lynafledere og derfor som beskyttelse af den enkelte gård. Den type tabutræer spillede endnu i det 19. århundrede i Sønderjylland en vigtig rolle $\mathrm{i}$ folkebevidstheden - specielt på Als. De er interessante, fordi traditionen må gå meget langt tilbage i tid og på grund af træart, alder og voksested. I beskrivelsen af træerne fremgår det, at mange er meget gamle og har været sikret ved jernbånd og andre foranstaltninger. På Als blev der i 1951 optalt 58 brandtræer, men mange af disse træer er i dag forsvundet. ${ }^{36}$

\section{Skovenes almene tilstand omkring 1700}

Als rummer i dag to forskellige slags skove: Statsskovene (de tidligere domæneskove) og de private »bønderskove«. På nutidens kort ses rester af de store skove, der strakte sig langs hele østkysten fra Nordborg til Skovby og Kegnæs - i dag Nørreskoven. De mange små skovrester på den vestlige side af Als og på Sundeved, Sønderskoven, Arnkil, Sottrupskov, Bøffelkobbel og andre småskove bekræfter, at store dele af Als og Sundeved har været dækket af skov. Det er hovedsageligt bøgehøjskov. I højskovene findes endnu mange gamle træer, som minder om tidligere tiders skovkultur. Der findes en hel liste over disse. ${ }^{37}$ Mange af de små private bønderskove har aldrig været under forstmæssig kultur. Dette kan ses i de første skriftlige beretninger over distriktets skove. Fra 1730 findes husfoged Danielsen og skovrider Johann Mathias Kochendorffers besigtelse af skovene i henholdsvis Nordborg og Sønderborg amter. ${ }^{38}$ Beskrivelsen dækker sko- 


\begin{tabular}{|c|c|}
\hline \multicolumn{2}{|l|}{ Ladegårdslen: } \\
\hline Sonderskov & $\begin{array}{l}\text { fă gamle bøge ... enkelte gamle ege ... i moserne og engene noget elleunderskov } \\
i \text { temmelig god stand ... }\end{array}$ \\
\hline Grønnekobbel & $\begin{array}{l}\text {... unge bøge og ege ... visse steder kraftige ege ... underskov af el og hassel } \\
\ldots\end{array}$ \\
\hline Mittelholtz? & ... Over - og underskov ... \\
\hline Endeles & $\begin{array}{l}\text {... enkelte gamle ege ... dog i god stand ... fa gamle boge ... underskov er el } \\
\text { og hassel ... }\end{array}$ \\
\hline Huholt & ... nogle ege og boge ... hist og her el ... \\
\hline Klinting & ... ganske fă gamle bøge og ege ... fả elle ... \\
\hline Stenholt & ... ligesom den just narnte ... \\
\hline Lambjerg Indtagt & ... yngre bogeskov ... få gamle ege ... underskov er el ... \\
\hline Ulkebøl & ... gamle ege ... underskov el og hassel ... \\
\hline \multicolumn{2}{|c|}{ Bondemarker/Ladegårdslen: } \\
\hline Klinting & ... enkelte bøge ... ege ... underskov er el ... \\
\hline Langdel & ... enkelte unge ege ... underskov er hassel ... \\
\hline Sondermark & ... enkelte egekrat ... underskov er el og tjørn ... \\
\hline Lambjerg & $\begin{array}{l}\text {... enkelte bøge ... enkelte egekrat ... underskov er el og tjorn ... unge bøge og } \\
\text { ege er ved at vokse op ... }\end{array}$ \\
\hline Miang & ... egekrat ... underskoven er el, hassel og tjorn ... \\
\hline Hørup & ... som det ovennxinte med undtagelse af hassel ... \\
\hline $\begin{array}{l}\text { Ulkebøl, } \\
\text { Sundsmark }\end{array}$ & $\begin{array}{l}\text {... ingen overskov ... underskov er el, hassel og tjorn ... enkelte unge ege er } \\
\text { ved at vokse op ... }\end{array}$ \\
\hline \multicolumn{2}{|l|}{ Ronhavegårdslen: } \\
\hline Sonderkobbel & ... enkelte egekrat ... underskoven af hassel $i$ god stand ... \\
\hline Hestehaven & $\begin{array}{l}\text {... enkelte egekrat ... og enkelte bøge ... underskoven er hassel og noget el og } \\
\text { bøg ... }\end{array}$ \\
\hline Arnkilsmaj & ... temmelig ung ege- og bøgeskov ... underskov er el lidt bøg og hassel ... \\
\hline Folekoppel & ... unge ege og boge ... underskoven sparsom ... \\
\hline Arnkil & ... bogekrat ... og egekrat \\
\hline Bjerrekoppel & ... meget lidt egekrat ... lidt underskov ... \\
\hline $\begin{array}{l}\text { Bondemarker/ } \\
\text { Ronhavegårdslen }\end{array}$ & ... ingen overskov ... enkelte gamle elle ... underskov består af el ... \\
\hline
\end{tabular}

venes navne, deres bestand og udseende, om det drejer sig om ege eller bøge, gammelt eller ungt træ, navnene på skovfogederne, hvor de bor og deres distrikt. Beskrivelsen, der er håndskrevet med gotisk skrift på plattysk, er på ingen måde særlig detaljeret. Sønderherreds skovdistrikt bestod af Ladegårds len, Rønhavegårds len, Majbølgårds len og Gammelgårds len. På næste side ses en oversigt over skovty- 
perne og skovenes tilstand $\mathrm{i}$ Ladegårds len og Rønhavegårds len på baggrund af beskrivelsen fra 1730 .

Umiddelbart ser skovenes tilstand omkring Sønderborg i begyndelsen af 1700-tallet ikke fuldstændig håbløs ud, men det er meget vanskeligt at bedømme, hvad eksempelvis udtrykkene "middelmådig, enkelte, nogle « dækker over, for det bliver jo bedømt i forhold til noget andet, som har været kendt for skovfogederne. Selve sproget i rapporten viser, at status bedømmes i forhold til tidligere tider. Set under den synsvinkel er skovene reducerede - men hvor meget? En umiddelbar optælling har som resultat, at der i 1730 var betydelig mere overskov end underskov i Rønhavegårds len. Det må betegnes som positivt. Men hvis vi ser samlet på Rønhavegårds len og Ladegårds len, viser det sig, at underskoven er sterst. Overskoven er reduceret til blot en tredjedel af den samlede skovmængde i disse to len. Vangeskove - altså træer og buske på bøndernes marker - fylder meget $\mathrm{i}$ opgørelsen over Ladegårds len, og her er bondemarkerne stort set blottet for overskov. En konklusion er derfor, at det især er bønderne, der har været synderne, fordi de har været hårde ved overskoven.

\section{Miljøhistorisk katastrofekurs omkring 1700}

I Danmark skelnes der generelt mellem to skovrydningsperioder. Den første periode går gennem stenalder, bronzealder og tidlig jernalder (3000 f.Kr.-400 e.Kr.). Den anden periode er vikingetiden (800-1000 e.Kr.), hvor en mere effektiv skovrydning satte ind. Det er også i denne periode, at bynavne med endelsen: -toft, -by, -mark, -torp/-trup/ -drup/-rup, -tved og -slet dominerer. Det fortsatte ind i Valdemarstiden (1150-1250) med bynavne, der endte på: -rød, -bøl og -holt.

Under vendernes plyndringstogter blev brede bræmmer land ud mod Østersøen opgivet som landbrugsområde. Disse sprang dernæst i skov. Det skete på Fyn, Lolland-Falster og på Als, hvor Nørreskoven dannede sådan en bræmme. ${ }^{39} \mathrm{I}$ middelalderen under perioden med ødegårde har skoven flere steder haft mulighed for at erobre terræn som tidligere nævnt. Hvis man skal forsøge at give et overordnet billede af skoven i Danmark som helhed fra 1500 til tiden med de store landboreformer omkring 1800, illustrerer det en miljøhistorisk katastrofekurs. ${ }^{40}$ Skovarealet blev reduceret voldsomt. På cirka 150 år i perioden mellem 1600-1750 blev Danmarks skovareal reduceret med 
16 procentpoint. I hektar svarer det til et skovareal 0,8 mio. ha., hvilket medførte at områder, der tidligere var bevokset med træer, blev ændret til hede og overdrev. Træfældningen gik specielt ud over tømmer- og oldentræer, hvilket bevirkede, at overskoven blev tynd. ${ }^{41}$ På Als har det været slemt, men måske ikke så slemt som i andre dele af Danmark. Der er således ikke tale om egentlige hedestrækninger på Als og Sundeved, og overskoven synes ikke at have ligget i fuldstændig ruin.

\section{Konklusion}

Skovrydningen accelererer for alvor i midten af det 16. århundrede og kulminerer på Als med Hertug Hans' totale indhug på Kegnæs i 1615. Det kan sammenlignes med rovdriften på de tropiske skove i vore dage. Så umiddelbart ville man benævne hertug Hans som en miljøforbryder af værste slags. Men set i sammenhæng med samtidens udfordringer er sagen mere kompliceret. Han udnyttede konjunkturerne og ressourcerne og greb mulighederne. Der ligger således en konflikt i den historiske anvendelse af skov og jord, som stadig er aktuel i nutidens debat om menneske og miljø.

Lensregnskaberne fra midten af 1500-tallet og de omtalte landsbynavne tyder på, at Als har haft meget skov; ja, måske har øen været det tættest bevoksede skovområde i Sønderjylland. Der har altså været nok af tage af, og lensregnskaberne med oldentallene og tilstandsrapporterne fra 1730 kunne tyde på, at Als relativt set ikke har været ramt så hårdt $\mathrm{i}$ perioden op til lovgivningen om fredning af skovene omkring 1800 som mange andre områder i Danmark. På trods af store pletter omkring Mintebjerg, Lambjerg, Klinting, Sundsmark, Ulkebøl, Skovby, Lysabild, Mommark og Kegnæs er Sønderskoven og den store Nørreskov stadig tilbage.

I dag er det politiske mål at øge arealet af skov i Danmark. Skovene skal fungere som rekreative områder for os alle, og skal ikke længere drives ud fra produktionsmæssige mål $\mathrm{i}$ form af træ til industrien. Dette gælder statsskovene. Men nogle af problemerne er de samme som tidligere, idet cirka $75 \%$ af skovene i Danmark er privatskove. Dilemmaet om skoven som ressourceområde er således det samme $\mathbf{i}$ dag som tilbage $\mathrm{i}$ historien. 


\section{LITTERATUR}

Andersen, Svend Th.: Fra urskov til kulturskov. Ugeskrift for jordbrug 1987, årg. 132 nr. 4.

Behrends, O.: Forandringer i underskoven i sønderjyske løvskove. Flora og fauna, 1951 s. 83-86.

Berntsen, Arent: Danmarckis oc Norgis fructbar herlighed 1656. Selskabet for udgivelse af kilder til dansk historie. 1971.

Bjerke, Sten: Om svin og skov. Dansk skovforenings tidsskrift, bd. 441959.

Bojesen, Christian Bo og Munksgaard, Jorn Arpe: Statsmagt og okonomi i det 16. og 17. årh. Sonderborg 1995.

Bricka, C.F. mfl. Kancelliets brevbøger vedrerende Danmarks indre forhold 1551-1648. 1885 ff.

Clausen, H.V.: Sønderjylland - en rejsehåndbog. Kbh. 1932.

Christensen, Hanne: Diger og hegn - elementer i kulturlandskabet. Sønderiydsk Månedsskrift nr. 10 oktober 1998.

Corpus Constitutionem Daniae. Forordninger, recesser og andre kgl. breve bd. 1-6. Udg. Valdemar Secher. Kbh. 18871918.

Danckwerths beskrivelse, 1649 ?

Danmarks Naturfredningsforenings årsskrift 1969: Vort landskab.

Dansk natur - dansk skole. Årsskrift 1982.

Dreyer, Valdemar: Norreskoven på Als. Fra Als og Sundeved 1992.

Eliasson, Per: Skog, magt og människor. En miljöhistoria om svensk skog 1800 1875. Malmö 2002.

Ethelberg, Per m.fl.: Det sonderjyske landbrugs historie - sten - og bronzealderen. Historisk samfund for Sonderjylland Haderslev 2000.

Falkenstjerne og Anna Hude. Sonderjydske skatte - ord jordebøger fra reformationstiden. 1895-1899. Rigsarkivet.

Fra Als og Sundeved 18. hefte 1942.

Fra Als og Sundeved: By og bolig - Sonderborg. Sonderborg Andelsboligforening/Historisk

Fritzbeger, Bo: Danske skove 1500-1800. En landskabshistorisk undersøgelse. Landbohistorisk selskab 1992.

Grau Møller, Per: Udskiftningen og dens okonomiske og sociale følger i Senderjylland ca. 1730-1830. Studier udgivet af
Historisk Samfund for Sønderjylland $\mathrm{nr}$. 1, Åbenrå 1984.

Gregersen, H.V.: Det skæve Sonderjylland - hvorfor?. Åbenrå 1990.

Hald, Kristian: Vore stednavne. 2. rev. udg., Kbh. 1965.

Hald, Kristian: Stednavne og bebyggelse på Als. Sønderjydske årbøger 1947, s. 122.

Hauch, L.A.: Skove på Als. Danmarks trævækst 1921, bd. 2, s. 140-145.

Historisk samfund for Als og Sundeved: Rejser og rejsende. Sønderborg 1964.

Skrift for historisk forening for Sundeved 1996.

Huhle, Robert, red.: Bogen om Als. Aabenraa 1956.

Iversen, Johs.: Danmark. Tidsskrift nr. 7. 1942. Østslesvigs natur.

Jensen, Jørgen Steen: Hertug Hans den Yngre. Historisk samfund for Als og Sundeved 1971.

Journal of danish archaeology Vol. 2. Odense universitet 1983.

Knudsen, Chr.: Samlinger til Als' historie. $\mathrm{Ny}$ kgl. Saml. $4^{\circ}$, Kgl. Bibliotek. (findes på mikrofilm på Sdb. Bibliotek).

Kjærgaard, Thorkild: Den danske revolution 1500-1800. Ålborg 1991.

Kulturhistorisk leksikon for nordisk middelalder.

Lauridsen, P.: Kartografen Johannes Mejer. Historisk tidsskrift, 6. række, bd. 1, 1887-88.

Mathiesen, Henning: Hertugens folk landbrugerne under Rønhave og Sønderborg Ladegård $\mathrm{i}$ tiden inden udskiftningen. Studier udgivet af Historisk Samfund for Sønderjylland nr. 7, Åbenrå 1992.

Petersen, Fr. Durch Wald und Flur. Heimatblätter nr. 9 november/december 1915.

Petersen, Fr. Bemärkenswerte Bäume und holzgewächse im Amte Sonderburg. Heimatblätter nr. 10, november 1922.

Petterson, Ronny red.: Skogshistorisk forskning i Europa og Nordamerika. 1999.

Petit, E.: Udkast til en floristisk beskrivelse af Als. Botanisk tidsskrift. 1881, bd. 12, s. $13-41$ og 1887 , bd. 18 , s. 6-11.

Pontoppidan, Erik: Den danske Atlas. To- 
mus VII, 1. Bind. Rosenkilde \& Bagger 1971.

Raben, J.: Fra Als og Sundeved 22. Hefte. Sonderborg 1945.

Rasmussen Porskrog, Carsten: Rentegods og hovedgårdsdrift. Godsstrukturer og godsøkonomi i hertugdømmet Slesvig 1524-1770. Institut for Grænseforskning 2003.

Schmidt; August F.: Spredte studier fra Als. Sonderborg 1951.

Schröder, Johannes v.: Topographie des Herzogthums Scleswig. Schleswig 1837.

Solvang, Gunnar: Husmandsliv under afvikling, Landbohistorisk Selskab/Historisk Samfund for Als og Sundeved 1999. S. 274-275, 278-290.

Sønderjyllands Amt: Kulturmiljøer og kulturhistoriske enkeltelementer i Sonderjylland. Aabenraa 2001.

Sønderjyske stednavne bd. 5: Sønderborg Amtsrådskreds. Kbh. 1939.

Worsøe, Eiler: Skovbilleder fra en svunden tid. Skovhistorisk selskab 2000.

Kort:

Et landkort over Als og Sundeved 1655/ Henrich Ottendorff. Historisk Samfund for Als og Sundeved 1990.

Sønderborg byhistorisk atlas. November 1982.

Målebordsblad over Als.

Sonderjyllands Amt: Kulturmiljøer og kulturhistoriske enkeltelementer i Sonderjylland. Aabenraa 2001.

Trap. Sønderjylland 1864 og 1922.

\section{NOTER}

1. Fritzbøger, Bo: „Danske skove - 15001800. En landskabshistorisk undersegelse«. Landbohistorisk selskab 1992.

2. Samme s. 16-18. Artiklen statter sig til Bo Fritzbøgers metode og begreber, uden at han dog skal gøres ansvarlig for denne undersøgelse.

3. Mathiesen, Henning: Hertugens folk - landbrugerne under Rønhave og Sønderborg Ladegård $\mathbf{i}$ tiden inden udskiftningen. s. 19.

4. Møller, Per Grau: Udskiftningen og dens økonomiske og sociale følger i Sonderjylland ca. 1730-1830. s. 41.

5. Huhle, Robert, red.: Bogen om Als.
Aabenraa 1956 s. 26-27. Ophavsmanden til pollenanalysen er dr. phil. Johannes Iversen fra Sonderborg.

6. Andersen, Svend Th.: Fra urskov til kulturskov. Ugeskrift for jordbrug 1987 årg. 132 nr. 4.

7. Ethelberg, Per m.fl. Det sønderjyske landbrugs historie s. 25-26, 34-36.

8. Bjerke, Sten: Om svin og skov. Dansk skovforenings tidsskrift bd. $441959 \mathrm{~s}$. 539.

9. Behrends, O.: Forandringer i underskoven i sønderjydske løvskove. Flora og fauna 1951 s. 83-86.

10. Thorkild Kjærgaard: Den danske revolution. Kbh. 1996 s. 94.

11. Corpus Constitutionem Daniae. Forordninger, recesser og andre kgl. breve bd. 1-6. Udg. Valdemar Secher. Kbh. 1887-1918. Schmidt; August F.: Spredte studier fra Als. Sønderborg 1951.

12. Bricka, C.F. mfl. Kancelliets brevboger vedrorende Danmarks indre forhold 1551-1648. $1885 \mathrm{ff}$.

13. "Forordning om jagten i vildtbanen" 13. maj 1662; "Forbud om huggen $i$ gejstlig godsers underliggende skove" af 15 . februar $1670 \mathrm{og}$ "Forordning og Skovordinance i Danmark « af 20. oktober 1670 .

14. Fallesen, L.S.: Chronologisk samling af de kongelige forordninger og åbne breve, forst - og jagtvæsenet $i$ det egentlige Danmark angående, som fra året 1660 til vore tider ere udkomne. Kbh. 1836.

15. Knudsen $X, 2$

16. Huhle, Robert, red.: Bogen om Als. Aabenraa 1956 s. 145.

17. Knudsen VII, 11.

18. Bo Fritzbeger: „Danske skove - 15001800. En landskabshistorisk undersegelse«. Landbohistorisk selskab 1992. s. 45.

19. Kristian Hald: Vore stednavne. 2. reviderede udgave. Kbh. 1965. Kristian Hald: Stednavne og bebyggelse på Als. Sønderjydske årbøger 1947 s. 122. Sonderjyske stednavne bd. 5: Sonderborg Amtsrådskreds. Kbh. 1939.

20. Solvang, Gunnar: Husmandsliv under afvikling, Landbohistorisk Selskab/Historisk Samfund for Als og Sundeved 1999. S. 274-275, 278-290. 
21. F. Falkenstjerne og Anna Hude. Sonderiydske skatte - og jordebøger fra reformationstiden. 1895-1899, s. 5 . Rigsarkivet. Knudsen VI, 1, VII, IX, 1, $\mathrm{XI}, \mathrm{XVI}$ og XXI, 18. Jørgen Steen Jensen: Hertug Hans den Yngre. Historisk samfund for Als og Sundeved 1971 s. 47. Rasmussen Porskrog, Carsten: Rentegods og hovedgårdsdrift. Godsstrukturer og godsøkonomi i hertugdømmet Slesvig 1524-1770. Institut for Grænseforskning 2003 s. 301.

22. I hertugdømmerne regnedes i lybsk enhed, for at mønten ikke skulle blive forringet. Møntenheden var mark og underenheden skilling. F. Falkenstjerne og Anna Hude. Sønderjydske skatte- og jordebeger fra reformationstiden. 1895-1899, s. 5. Rigsarkivet.

23. Knudsen XXI, 18.

24. Bo Fritzbeger: »Danske skove - 15001800. En landskabshistorisk undersegelse «. Landbohistorisk selskab1992. s. 38.

25. Knudsen XVI.

26. Skoletjenesten 1987: Kulsvierlandet. s. 34.

27. Samme s. 70 .

28. En læst á $3 \mathrm{~m}^{3} \times 738$ læster giver 2. 214 $\mathrm{m}^{3}$ trækul, hvilket fører frem til, at der sammenlagt er gået $3 \times 2.214 \mathrm{~m}^{3}=$ $6.642 \mathrm{~m}^{3}$ træ til at fremstille trækullet. Hvis dette bliver omsat i træer, giver denne beregning, at $6.642 \mathrm{~m}^{3}$ træ: 6 $\mathrm{m}^{3}=$ ca. 1.107 træer sammenlagt er fældet i 1524 og 1535. Det samlede skovareal, der er gået til at fremstille trækul bliver dermed 1. 107:50 $=22,14$ og $22,14 \times 181 \mathrm{~m}^{2}=4.007 \mathrm{~m}^{2}$. Til trækulsfremstilling er der således $\mathrm{i}$ årene 1524 og 1535 gået $4.007 \mathrm{~m}^{2}$ skov. Lensregnskaberne viser, at der i 1524 blev afleveret 1. 638 læs brændeved, som giver $(1.638 \times 2) 3.276 \mathrm{~m}^{3}$ fældet træ, og i 1535 blev der afleveret 1.852 læs brændeved, som giver $(1.852 \times 2)$ $3.704 \mathrm{~m}^{3}$ fældet træ. Det samlede antal traer, som er gået til brandeved bliver dermed $6.980 \mathrm{~m}^{3}: 6 \mathrm{~m}^{3}=1.163$ træer, som sammenlagt er fældet $i$ 1524 og 1535. Omsat i skovareal bliver det til, at $1.163: 50=23,26$ og 23,
$26 \times 181 \mathrm{~m}^{2}=4.210 \mathrm{~m}^{2}$ skov i $1524 \mathrm{og}$ 1535 er gået til at fremstille brændeved.

29. $4.108 \mathrm{~m}^{2} \times 11=45.188 \mathrm{~m}^{2}$ skov.

30. Jensen, Jargen Steen: Hertug Hans den Yngre. Historisk samfund for Als og Sundeved 1971 s. 32.

31. Jensen, Jørgen Steen: Hertug Hans den Yngre. Historisk samfund for Als og Sundeved 1971 s. 65.

32. Knudsen VII, 11, Danckwerths beskrivelse 1649. Berntsen, Arent: Danmarckis oc Norgis fructbar herlighed 1656. Selskabet for udgivelse af kilder til dansk historie. 1971. s. 120-121. Om Als. Pontoppidan, Erik: Den danske Atlas. Tomus VII, 1. 1781 s. 104-105. Rosenkilde \& Bagger 1971.

33. Historisk samfund for Als og Sundeved: Rejser og rejsende. Sonderborg 1964 s. 30.

34. Knudsen XI, 1 og XVI.

35. Huhle, Robert, red.: Bogen om Als. Aabenraa 1956 s. 37. Schröder, Johannes v.: Topographie des Herzogthums Scleswig. Schleswig 1837 s. 9.

36. Schmidt; August F.: Spredte studier fra Als. Sønderborg 1951 s. 61-71.

37. Petersen, Fr.: Bemärkenswerte Bäume und holzgewächse im Amte Sonderburg. Heimatblätter nr. 10 november 1922.

38. "Beskrivelse af skovene i Sønderborg amt på øen Als efter den af husfoged Danielsen og skovrider Johann Mathias Kochendorffer den 21. november 1730 afholdte og af jægermester Bachmann indsendte besigtigelse «, Rigsarkivet: Rentekammerets arkiv nr. 333.24: 1705-1734 Beskrivelser af skovene $\mathrm{i}$ hertugdømmerne og grevskaberne (1 pk). En mere nøjagtig opmåling og kortlægning fra 1819-21 er forsvundet. (Hverken Gråsten skovdistrikt eller landsarkivet i Ảbenrå kan finde dem).

39. Kulturhistorisk leksikon for nordisk middelalder: Skog.

40. Grafen er udarbejdet på baggrund af Den store Danske Encyclopædi, bind 4 , side 472 .

41. Fritzbøger, Bo: »Danske skove - 15001800 s. 284. 